\title{
Premodern'den Postmodern’e Benliğin ve Kutsalın Dönüşümü: Narsisist Benliğin Kutsal Algısı
}

\author{
AHMET GÜVEN* \\ adilhikmet84@gmail.com
}

\begin{abstract}
Özet: Benlik kavramını, vülgarize ederek söylemek gerekirse, modern öncesi ve sonrası olmak üzere ayırmak gerekir. Modern düşüncenin "bilgi”nin mahiyeti üzerinde meydana getirmiş olduğu dönüşüm öncelikle benlik algısını ve kaçınılmaz olarak kutsal algısını değiştirmiştir. Geleneğin içinde merkezi konuma sahip olan "kutsal bilgi" (scentia sacra) benliğe, ancak "Külli akl" (intellect) ile varlı sahası tanımış ve benliği terbiye edilmesi gereken "nefs" olarak görmüştü. Modern düşünce ise "bilen" ve "bilinen" benlik ayrımını yaparak bilginin merkezini ilahi olandan beşeri olana taşıyarak bilginin "desacralizasyonunu" (kutsallıktan arındırma) temin etmiştir. Geleneğin çok katmanlı hakikat telakkisi yerine geçen modernizmin tek boyutlu ve dayatmacı hakikat algısına tepki olarak postmodern zamanlarda hakikatin ulaşılamaz olduğu fikrine dayanan hakikatin izafiliği düşüncesi doğmuştur. Bu postmodern düşünce narsisist benliğin ortaya çıkışında en etkili unsurdur.
\end{abstract}

Anahtar kelimeler: Bilgi, benlik, Narsisist benlik, Kutsal, Scentia sacra.

\section{Giriş}

"Ben" kavramı modern bilimin alanına girmeden önce hemen her kültürde ve dinde bir bütün olarak ele alınmış normatif bir kavramdı. Antik Yunan'da Sokrates'e, Çin'de Konfüçyüse', Hindistan'da Buda'ya, İslam'da sufi ve melâmi ekollerine, Hıristiyan mistisizmine kadar modern öncesi birçok akımda benlikten bir bütünlük olarak bahsedilmiş ve yüksek bir ahlak Tanrıya ulaşmanın bir aracı olarak görülmüştür. Delphi'deki Apollon Tapınağının girişindeki "kendini bil” sözü ve "kendini bilen Rabbini bilir" anlamındaki kutsi hadis, benliğin ancak kemale ulaşabilmek için inceleme alanı haline getirilen bir kavram olduğunu vurguluyordu. İnsanın benliğini ortaya çıkarması günah kabul edilirdi. Esasında benlik yaratıcıda sabitlenmesi murad edilen fakat her an hareket halinde olduğu için insana büyük güçlükler çıkaran bir "nefs" terbiyesi süreciydi. Hz. Ali bu bağlamda benliği bir koyun sürüsüne benzetir ve nereden ürkütülürse oradan bozulan, devamlı değişim halinde olan bir mahiyete sahip olduğunu vurgular (Nurbahş, 2009, s. 24). Benlik ya da nefs ilahi birlikte (vahdet) yok olması gereken fakat öldürülmesi değil terbiye edilmesi gereken bir bilme aracıydı. Bu "bilme"nin yolu ise, farklı din ve felsefelerde farklı isim ve şekillerde ortaya çıan fakat hakikati tek olan "hikmet" denilen kutsal bilgiden (scentia sacra) geçmekteydi.

\footnotetext{
* Arş. Gör., Marmara Üniversitesi İletişim Fakültesi, Halkla İlişkiler ve Tanıtım Bölümü.
} 
Modern dönemin psikoloji literatürü benliği, insanın kendini ve içinde bulunduğu evreni anlamlandırma çabası sonucunda edinmiş olduğu zihinsel bir şablon, zihinsel süreçleri içermesi sebebiyle bilinç düzeyinde gerçekleşen yani kişinin kendisiyle ilgili farkında olduğu yanı olarak görür. İnsanların kendileri hakkındaki bilgilerine gönderme yapması dolayısıyla kişiliğin bilişsel yanını ifade eder (Drever, 1952, s. 262). Benlik insanın kendisini, bilinçli olarak nasıl algıladığıdır. Kim olduğu, ne olduğu, ne gibi yeteneklere sahip olduğu, değeri ve değer yargıları gibi kendisiyle alakalı bütün bilgi, duygu ve tutumlardır. İnsanın kendisi hakkında sahip olduğu inançlar bütünü benliktir (Sears vd., 2010, s. 105). Benlik, kişinin kendini herkesten başka ve ayrı eşsiz bir bütünlük olarak hissetmesi, bunun bilincinde olması ve bilincinde olunan bütün bir varlıktır. Tüm çalışmalarda ortak nokta kendi bilincinde olma ve iradi eylem yetisidir (Ekşi, 2012, s. 36).

Görüldüğü gibi premodern dönemdeki benlik düşüncesi tamamen kutsal bilginin güdümünde olduğu için ilahi menşelidir. Modern dönemin tanımları ise benliğin merkezini ilahi olandan insani olana getirmiş, bilgiyi kutsaldan arındırdığ 1 gibi benliği de kutsaldan arındırmıştır. Bu dönüşümün mihenk noktasını, modern felsefenin kurucusu kabul edilen Descartes'in “cogito ergo sum” (düşünüyorum o halde varım) önermesi teşkil eder.

\section{Premodern Benlik Algısı ve "Cogito"}

Descartes'in ünlü "cogito" önermesinde "ben” gözlemleyen bir bilinç haline gelmiştir. Her şeyden şüphe eden Descartes şüphe edebilen bir "kendilik bilincinin” farkına varır. Her şey şüphenin konusu olabilirken şüphe etme edimini gerçekleştiren, yani düşünen ben şüphenin dişına çıkar. Çünkü şüphe etmek bir eylemdir ve bunu yapan benlik bir fail durumuna geçer. Dolayısıyla bu öznenin varlığından şüphe edilemez. Düşünen benlik, vardır. Öyleyse eşyayı bilimsel bir yöntem ile ele alırken referans noktası özne olan (bilen) benliktir (Yalçın, 2008, s. 92).

Descartes bu düşüncesiyle kesin bilgiye yeni bir temel arayışındadır. Hem Külli Akl’ı (intellekt) hem de vahyi göz ardı ederek kendisine rehber olarak, düşünen öznenin ferdi bilincini seçer. Bu durumda özne ile nesne, bilen ile bilinen ayrılır ve özne, nesne karşısında ön plana geçer. Esasında "cogito", derin bir metafizik içerebilecek şekilde kurgulanmıştır ancak Descartes bunu söylerken “ilahi ben”e işaret etmez. Sözün, "ilahi ben"e işaret eden bu şekli bazılarının dediği gibi "cogito ergo est" (düşünüyorum o halde Tanrı var) veya Hallac-1 Mansur'un ifadesiyle "Enel Hak" şeklindedir. Böyle bir şekil geleneksel felsefenin ifadesi olarak kalacaktı. Fakat hikemî bakış noktasından bu görüş, kişinin kendi hal ve bilincini ortaya koyan "vehmî ben"i meydana getirir (Nasr, 2012, s. 65). Böylece felsefenin temel ilgisi ontolojiden epistemolojiye kaymış olur. Nesneler âlemi aklın (reason) alanına tutsak hale gelmiş, hem Akl'dan (intellekt) hem de vahiyden kopmuştur. Böylece bilginin imkânı Akl ve vahiy olmaktan çıkmış, bilgi kutsal muhtevasından arındırılmaya başlanmıştır (Nasr, 2012, s. 66).

$\mathrm{Bu}$ ayrılma, parçalanma ve bilginin desacralizasyonu, Walter Ong ve Marshall McLuhan gibi düşünürlerin ortaya koydukları gibi söz ve yazı karşıtlığıyla derinden ilintilidir. Ong, sözlü kültürlerin yani sesin psikodinamiğini incelerken söze birlești- 
rici nitelikler atfeder. Buna göre duyulardan hiçbiri nesnenin iç ve dış yapısını, işitmenin yapabildiği şekliyle kaydedemez. Görüntü parçalayıcıdır, işitme ise birleştirir. Bir nesneyi görmek için nesneden uzaklaşmak gerekir fakat ses insanın içine akar. İnsan sesin içine gömülebilir fakat görüntüye gömülemez (Ong, 2013, s. 90-91). Sözün görüntüye dönüşmüş hali olan ve bilgiyi insan zihni dışında başka bir mekânda kayda geçirme imkânını veren yazı açı seçiktir, belirgindir, analiz etmeye elverişlidir. Sözlü kültürlerde nesnelerin analiz edilmesi söz konusu olmaz. Ancak yazının basılmasıyladır ki insan kendi benliği üzerine düşünebilme ve onu analiz edebilme imkânına kavuşmuştur. Bu da elbette benliğin "bilinen benlik" tarafını "bilen benlikten" ayırma yani benliği nesne haline getirebilme ile mümkün olur. Fakat bu durum kutsalın terk edilmesini de kaçınılmaz hale getirir. Sözün dünyası birliğin dünyasıyken, yazının dünyası bireyselliğin dünyasıdır. Kendi iç dünyasına dalan insan artık bireyselleşme yolunda en önemli adımı atmış ve bilginin laikleşmesini imkân dairesine sokmuştur.

Sözlü kültürün yani premodern dönemin insanları, (modern felsefenin ancak matbaanın yaygınlaşması sonucunda ortaya çıkabildiğini düşündüğümüzde) zihinsel soyutlamalara ve soyut kategorilere açık değillerdi. Bir saha araştırmasında ${ }^{1}$ okuryazar olmayan köylülere, nasıl bir kişiliğe sahip oldukları, nasıl bir insan oldukları gibi benliğe dair sorular sorulduğunda alınan cevaplar nereden göç ettiği, ne kadar tarlası olduğu, kaç çocuğu olduğu gibi benlikle ilgisi olmayan somut dünyaya ilişkin cevaplar olmuştur. Soru örneklerle açıklanarak tekrar sorulduğunda verilen cevap "biz terbiyeli insanlarız, kötü olsak kimse bizi saymazdı” şeklinde olmuştur. Değerlendirme yine benlik algısı düzeyine inmemiş "biz" şeklinde bir grup değerlendirmesi olarak kalmıştır. Aynı soruya başka bir okuryazar olmayan köylünün cevabı ise şöyledir; "Kendi gönlümü ben nasıl tarif edeyim? Nasıl olduğumu nasıl söyleyeyim? Başkalarına sor, onlar beni anlatsın” (Ong, 2013, s. 72). Bu ve benzeri örneklerde görüldüğü üzere premodern insan için "bilen ve bilinen benlik" ikiliği söz konusu değildir.

Yazının, bilinçte meydana getirdiği değişim ve bilginin laikleşmesinin ilginç bir örneğini de McLuhan verir. Kralların cenaze törenlerinde yeni bir ritüel olarak ortaya çıkan "kralın iki bedeni” uygulaması, Orta Çağ Avrupası'nda, önce İngiltere’de daha sonra Fransa'da görülmeye başlandı. Tören esnasında tabutun içindeki kralın ölümlü bedeni ile maketten yapılmış olan temsili bedeni beraber taşınıyordu. Ölümlü beden sıradan bir cenaze gibi düşünülüyor, kralın yaşarken taşıdığı ve siyasal erkini gösteren tüm kraliyet sembolleri maket bedenin üzerinde teşhir ediliyordu. Bunun esas sebebi Batılı zihnin, ölümlü beden ile onun temsil ettiği ölümsüz ihtişam arasındaki çelişkiyi görmeye başlamasıydı. Zamanla törenlerde maket bedene gösterilen saygı ölümlü bedene gösterilenin çok üzerine çıktı. Buradaki espri şuydu ki, Tanrı’nın yarattığı ölümlü beden geçiciydi fakat insanın yarattığı makamın temsili ölümsüzdü. Bir başka ifadeyle ölümsüzlük, Tanrısal aklın değil tamamen insan yapımı olan dünyevi bir siyasal kurumun ölümsüzlüğüydü (McLuhan, 2001, s. 172-177).

1 A.R. Luria, “Cognitive Development: Its Cultural and Social Foundations”, Luria bu çalışmayı Lev Vygotsky’nin cesaretlendirmesiyle Sovyetler Birliğiinin Özbekistan ve Kırgızistan bölgelerinde 1931-32 yıllarında gerçekleştirmiştir. Ayrıntılı Bilgi İçin Bkz. Walter Ong, 2013, s. 66-72. 
Bir bedendeki temsiliyetin bu şekilde ayrıştırılabilmesi McLuhan’a göre insanın bilincindeki değişim sonucu tipografik insanın ortaya çıkmasıyla mümkündü. Bu da elbette fonotik alfabeye ve onun matbaa vasitasıyla basılmasına bağlıdd. Ancak bu durum, ilerleyen süreçlerle beraber, uygulanabilir bilginin yükselişine, dünyanın zihinsel olarak yeniden düzenlenmesine, bireyselliğe, ulusalcılığa ve dünyanın sekülerleşerek birlik fikrini yitirmesine sebep olacaktı.

Premodern dünyanın benlik algısı kutsalın bilgisi bağlamında ele alınan bütüncül bir algıydı. Örneğin, Sokrates'te "kendini bilme" veya "kendine odaklanma" kavramı insanın ne yapmış olduğu ve ne yapmak zorunda olduğuna dair bir anımsama şeklinde bir benlik incelemesiydi (Foucault, 2001, s. 64). Bu bir anlamda nefs muhasebesi demekti. Benzer şekilde 8. ve 9. yüzyıllarda Horasan bölgesinde ortaya çıkan bir İslam tasavvuf ekolü olan Melamilik’te benliğin bilinen kısmı olan toplum düşüncesine atıflar vardır. Sufi ekolünden farklı olarak Melamiler hırka giymeyi (sufilerin yaptığ1 gibi) veya herhangi başka bir şekilde toplumda farklılaşmayı günah sayıyorlardı. Toplumdan farklılaşmamak, iyi özellikleriyle toplum tarafından bilinmemek, iyilikleri halktan gizli yapmak ve kusurlarını halka göstermek gibi prensipleri vardı (Bolat, 2003, s. 169-170). İlk Melamilerden sayılan Ebu Turab’ın "Halkla münasebetin ateşle münasebetin gibi olsun. Faydasından istifade et zararından sakın.” (Bolat, 2003, s. 86) sözü halkla araya mesafe koymayı dolayısıyla nesne konumundaki bilinen benliği ortaya çıkarmamaya yönelik bir anlayışı ifade eder. Benliğin bütünlüğünü korumak modern öncesi dönemdeki hemen hemen bütün din ve öğretilerde önemli bir yer tutar. Ancak Orta Çağ Avrupası'nda bu durum dünyadan ve evlilikten vazgeçme, kendini cezalandırma gibi bir Hıristiyan çileciliğine dönüştü. Benlikten vazgeçme değil benliği geliştirme çabası olan premodern benlik algısı, Hıristiyanlığın ilerleyen dönemlerinde "ben’in ifşası"na yani kefaret ve günah çıkarma ayinlerine evrildi (Foucault, 2001, s. 73). Kefaret ve günah çıkarma bir benlik ifşası ve benlikten kopma durumudur. $\mathrm{Bu}$ insanın kendi iradesinden vazgeçmesi ve külli iradede yok olması halidir. Tefekkür, Hıristiyan çileciliğinin bir diğer özelliğidir. Sürekli olarak Tanrı’yı düşünmeye çalışan keşiş düşüncesinin akışını devamlı irdeleyerek Tanrı düşüncesiyle diğer düşünceleri birbirinden ayırmaya çalışır (Foucault, 2001, s. 81). Devamlı hareket halinde olan ruh bir kargaşa ve huzursuzluk meydana getirir. Kurtuluş ancak benliği Tanrı'da sabitlemekle mümkündür. Buda’nın bir ağaç altında 49 gün boyunca aralıksız meditasyon yapması veya İslam Peygamberi’nin Hira Mağarası'nda riyazete çekilmesi benzer durumlardır.

\section{Modern Dönem ve Parçalanan Benlik}

Modern dönemin neredeyse tüm tartışmalarını eserlerinde bulabildiğimiz Jean-Jacques Rousseau benliğin biricikliği üzerinde israrla duran ilk düşünür olmuştur. Özerk benliğin vurgulanışı ve atomistik toplumun ortaya çıkışı Rousseau'nun İtiraflarım'daki aşırı duyarlılığı ve liberaller tarafından sahiplenilen Emile'deki doğalcılığı ile açılan bir yoldur. Rousseau "zihnim kendi zamanı içinde ilerlemeye ihtiyaç duyar, bir başkasının zamanına boyun eğmez. Çünkü biliyorum ki, kendi deneyimim bir başkasına uygulanamaz." derken benliğinin benzersiz olduğuna, duygunun önceliği 
ne ve benliğinin şimdiki haline zaman içinde geldiğine vurgu yapar (Foucault, 2001, s. 89). İtiraflarım'da şöyle der Rousseau:

Güvenebileceğim tek sağlam rehber, hayatımın dönüm noktalarını işaretleyen zincirleme duygular ve onların yardımıyla da bu duyguların ya sebebi ya neticesi olmuş olan bir sıra olaylardır. Başıma gelenleri kolay unuturum ama hatalarımı unutamam, hele güzel duygularımı hiç. Onların hatırası gönlümden silinemeyecek kadar kıymetlidir. Olaylarda unutkanlıklarım olabilir, onları birbirine karıştırabilirim. Tarih hatalarına düşebilirim. Fakat ne hissettiklerimde aldanırım ne de duygularımın bana yaptırdığ 1 hareketlerde. Yazılarımın başlıca konusu da budur. İtiraflarımın öz amacı, hayatımın bütün durumlarında içimden ne geçmişse tam olarak açıklamaktır. Sizlere vereceğim ruhumun hikâyesidir; bunu sadakatle kaleme almam için de başka vesikalara ihtiyacım yok. Şimdiye kadar yaptığım gibi kendi iç âlemime dalmam kâfi (Rousseau, 1991, s. 7).

Rousseau bu cümlelerle "ben"i "ben olmayan"dan ayırır ve kendi benliğini kurar. Kendi benliğini bir nesne gibi inceler ve bu sayede benliğini özne olarak da kurmuş olur. Bilen benlik ile bilinen benlik ayrımı ilk defa bu kadar keskin bir şekilde ortaya konmuş olur. Bunu yaptıran bir nevi günah çıkarma ritüeli olan itiraf mekanizmasının yeni bir teknikle ortaya konmasıdır. Foucault şöyle der:

Batılı insan itiraf eden bir hayvana dönüşmüş durumda. Edebiyat, gerçekleşen bir metamorfozdan beri kahramanlık ya da yiğitlik ve azizliğin yargılanmasında odaklanan öykülerden aldığımız zevkten; 'itiraf'ın, sözcüklerin arasında titrek ışıklarıyla parlayan bir mucize gibi belirdiği, benliğin derinliklerini sonsuzcasına ortaya koymak ödevine uygun düzenlenmiş bir edebiyata geçtiğimizden bu yana, 'itiraf' konuşan 'suje’nin (öznenin, failin) aynı zamanda ifadenin 'süje’si (konusu, nesnesi) olduğu bir söylem ritüelidir (Foucault, 2001, s. 84).

Bu durum hikemî (gnostik) bakıştaki (Melamiler'de olduğu gibi) ayıplanma ve kusurlarla nefsi terbiye etmenin tam tersidir. Rousseau İtiraflar'da inşa ettiği bu bireyselleşmiş benliğin mutluluk vermediğini Yalnız Gezenin Düşleri’nde fark eder. Yine de İtiraflar'ın meydana getirdiği etki küçümsenecek gibi değildir ve bireyselleşmiş modern bireyin temelini oluşturur (Foucault, 2001, s. 108).

Descartes, Spinoza ve Leibniz gibi benliği özne olarak alan rasyonalist düşünürlerin yanı sıra benliği nesne (bilinen) benlik olarak kabul eden ampirist düşünürler de vard1. Berkeley, Locke ve Hume gibi ampirist düşünürlere göre benlik bir töz olarak mevcut değildir. Bilen bir benlik yoktur yalnızca algılanan benlik vardır. Hume şöyle der:

Benliği hiçbir zaman bir algı olmadan yakalayamıyorum; yakaladığım şey her zaman bir algı olmaktadır. Örneğin uykuda olduğu gibi benliği hissetmediğim zaman yani algılarım olmadığı zaman, benim gerçekten var olmadığım söylenebilir (Hume, 1978, s. 252). 
Kant’a göre “düşünüyor” olmanın kendisi var olmak için yeterlidir. Ayrıca "o halde varım” demeye gerek yoktur. Kant düşünen bir benliğin varlığını bu şekilde kabul eder ancak bu önerme düşünen benliğin mahiyetini açıklamaz. Kant, (2001) Pratik Usun Eleştirisi, Aklın Eleştirisìnde benliğin bu bölümlenmesi üzerine uzun bir mülahazaya girer ve benliği; kendinde şey olarak benlik, düşünen (transandantal) benlik ve fenomenal benlik olarak üç gruba ayırır.

Aydınlanma ile bölünmeye başlayan benlik Freud'da en çarpıcı ifadesini bulur. Freud'a göre benlik "şimdi”nin bir eseri değildir. Benlik yalnızca içinde bulunulan zaman içinde kavranan bir "bilen” ve "bilinen" ikiliğine indirgenemez. Bilinçli kavrayışın yanında benliğin farkında olmadığı ve geçmiş deneyimlerin bastırılmasıyla oluşan bir bilinç dışı vardır. Freud benliği topografik kurama göre üç bölümde inceler; bilinç, bilinçaltı ve bilinç dışı (Yıldız, 2006, s. 93-94). Bilinç, algı ve bilgilerin açık seçik izlendiği duygu, düşünce, tutum, heyecan ve davranışa ilişkin haberdarlığın bulunduğu süreçtir. Bu görüşe göre bilinç o anda yaşananları kapsar. İnsan neyin farkındaysa, neyin bilgisine sahipse o andaki bilinç odur. Yani tek bir anda tek bir duygu veya düşünce bilinç alanında yer alır. Bilinçaltı ise bilince çıkabilme ihtimali olan bütün her şeyin depolandığı alandır. Rasyonel ve hayali her türlü süreci içerir. Bilince yakın olan, hemen bilinçli olacak bilgiler, anılar ve düşüncelerden oluşur. İnsan tek bir anda tek bir şeyin bilincindeyken bir saniye sonra başka bir düşünceyi bilincine dâhil edebilir. Bilinç dışı ise bilinçli algılamanın dışında kalan ve bilince çıkması engellenen her türlü zihinsel süreci kapsar. Engellendiği için rahatça bilince çıkamayan bu zihinsel süreçler semboller ve davranış, konuşma ve tutumların farklı anlatım yollarıyla açı̆̆a çıkarlar.

Topografik yaklaşımın temelini oluşturan bilinç, bilinçaltı ve bilinç dışı kavramları üzerine çalışmaya devam eden Freud bilinç dışı kavramının yerine id kavramını kullanmaya başladı. Topografik kuramdan yapısal kurama geçen Freud, benliği id, ego ve süper ego kavramlarıyla tanımladı. İd'i genetik olarak gelen içgüdüleri içeren ve doğuştan var olan psikolojik gizil güçlerin tamamı şeklinde tanımlamak mümkündür. İd ruhsal enerji kaynağı olarak tanımlandığı için ego ve süper egonun da çalışması için gerekli olan gücü de sağlar. Bütün benlik sistemini çalıştırmaya yetecek kadar enerjiyi biyolojik süreçlerden sağlar. Ego ise benliğin rasyonel tarafını oluşturur. İlkel arzuları temsil eden id ile toplumu temsil eden süper ego arasında uzlaştırıcı görevi vardır. Toplum tarafından hoş karşılanmayan id, ego tarafindan denetim altına alınır. Gerçekçi ve rasyonel olmayan süreçleri, yani id'i bilinç dışı kılarak bilincin ve bilinçaltının alanından çıkarır (Yanbastı, 1996, s. 18-23).

Benliğin tarihsel gelişimi ve benlik algısı dönüşümünün önemli basamaklarından biri de varoluşçuluktur. Kierkegard, Jaspers, Heideger, Sartre ve Camus önde gelen varoluşçulardandır. Varoluşçu filozoflara göre insan bir projedir. İnsan, benliğini keşfetmekle değil benliğini kurmakla görevlidir (Ekşi, 2012, s. 53). Çünkü insanın “öz”ü doğuştan gelmez.

Önde gelen varoluşçulardan biri olan Sartre var olmanın özden önce geldiğini söyler. Bunu yaparken tohum metaforunu kullanır. Bir tohumda bir ağacın özü gizlidir. 
Tohum toprağa düştüğü ve optimum şartlar sağlandığı zaman ortaya çıkacak olan ağacın özellikleri baştan bellidir. Yani öz varoluştan önce gelir. Ancak bu durum insan için geçerli değildir. İnsan önce bir varlık olarak imkânlar dünyasında yer alır ve daha sonra eylemleri ve seçimleriyle özünü oluşturur. Sartre şöyle der:

İnsan doğası diye bir şey yoktur, insan kendini nasıl yapıyorsa öyledir; varlığının temel seçmesi olan bu tasarıyla önce kendini belirler ve sonra gidişatının bütünü içinde ortaya çıkar. Bu tasarıyla insan, kendini seçerken bütün insanları da seçmiş olur. Çünkü o tasarıyla, gerçekleştirmesi gereken bir insan imgesi kurar. Onun için seçme bir değerlendirmedir. Böylece, her insan her an bütün insanl1ğa bağlanır. İşte, varoluşçuların bunaltıyı özgürlük içinde bırakılmışlığın bir belirtisi gibi görmeleri bundandır. Bunaltı bir yerde gelip sorumluluk duygusuna yani eyleme ve ahlaka dayanır. Varoluşçuluk, ahlaki bir nesnel değerler üzerine değil, insanın kökten özgürlügüne yaslandırılır. İnsan özgür olmaya mahkûmdur (Sartre, 2002, s. 92).

Önemli varoluşçu düşünürlerden bir diğeri, Albert Camus “absürde” ve başkaldırı kavramlarıyla bilinir. Camus tam bir bunalım felsefesi ortaya koyar ve ölümden dolayı umudu ve anlamı yok eder (Gündoğan, 1995, s. 52). Ona göre sorulması gereken ilk felsefi soru intiharın gerekli olup olmadığıdır (Camus, 2002, s. 15). Çünkü insan tıpkı Yunan mitolojisindeki Sisifos'un defalarca aşağıya yuvarlanan kayayı tekrar tekrar dağın tepesine kadar çıkarması eyleminde olduğu gibi bir anlamsızlık içerisindedir. İşte absürde/saçma olan bu hayatı yaşamaya devam etmek için insanın nasıl bir gerekçesi vardır?

Heidegere göre insanın dünya ile karşılaşması bilgi ile değil eylemle olur. Eylemi meydana getirecek olan yönelmeyi kaygı ile açılar (Akarsu, 1998, s. 216). İnsan dünyaya bırakılmıştır. Dünya insanın ana yurdu değildir. Bu yabancılık içinde insanın yolunu bulabilmesi için benliğini tanıması ve özgürleşmesi gerekir.

Tüm varoluşçularda görülen bu metafizik yurtsuzluk algısı (atılmışlık, bırakılmışlık, yabancılık) bir isyan duygusunun (başkaldırı) temelidir. Varoluşçu felsefenin büyük kötülük yılları olarak nitelendirilebilecek dünya savaşları sırasında ve sonrasında takipçi bulması tesadüf değildir. Milyonlarca insanın öldüğü, sürgünlerin yaşandığı, kimyasal ve nükleer bombaların kullanıldığı, işkencelerin yapıldığı bir kaos dünyasında insanın kendini evinde hissetmesi elbette mümkün değildi. Bütün bu şeytani kötülükler insanlığı büyük bir karamsarlığa sürüklemişti. İlahi bir unsurun kötülüklere dur demediği bu yıllar Tanrı fikrinin belki de en derinden sorgulandığı dönemdi. Öyleyse insan kendi benliğini kendisi kurmalıydı çünkü keşfedilecek, ilahi bir dokunuşla meydana gelmiş bir benlik yoktu.

18. yüzyıl öncesinde insan tarihsel koşullar içinde yer alan bir varlıktı fakat tarihsel koşulların bir sonucu değildi. Hem bilincin ilkeleri hem de duygu durumları genel geçer ve evrenseldi. Bu anlayış Vico, Darwin ve Marks’ın çalışmalarıyla birlikte yıkıldı. Artık insan biyolojik, kültürel ve ekonomik şartların bir ürünü haline gelmişti. Psikolojide William James felsefede Hanry Bergson bilinci zaman içinde sürekli hareket halinde olan bir akış olarak betimledi. Bu, Heraklietos'un aynı ırmakta iki defa 
yıkanılamayacağı önermesine bir dönüştü. Artık evrensel bir insan doğası düşüncesi yikiliyordu (Sennett, 2011, s. 16-17).

Heraklietos ile Parmenides’in tartışması ontolojik düzeyde bir tartışmaydı. Herakleitos her şeyin bir akış içinde olduğunu, zıtlıkların bir uyum meydana getirdiğini söylüyordu ama onun felsefesi bir bilinemezciliğe varmıordu. Tüm madde âlemi devamlı bir akış halinde olmasına rağmen bu akış belli bir düzene göre oluyordu. Asla durmayan akışın ardında ölçü koyucu bir hakikat gizliydi. Parmenides ise varlığın var olduğunu ve Herakleitos’un bu hiçlik felsefesinin doğru olmadığını söylüyordu. Sokrates ile sofistler arasındaki tartışma ise bir bilinemezcilik ile evrensel hakikatin mücadelesi şeklinde oldu. Sofistlere göre insan, her şeyin ölçüsüydü ve hiçbir genel geçer ahlak ilkesinde söz etmek mümkün değildi. Bu iddia tam bir subjektiviteye ve bilinemezciliğe varıyordu. Sokrates ve onun takipçisi Platon'a göre ise zaman ve mekân dışı erdemler vardı ve insan bu erdemleri yakalamanın peşinde olmalıydı (Cevizci, 2012, s. 222). Örneğin iyilik, adalet, dürüstlük gibi erdemler sofistlere göre zamandan zamana ve mekândan mekana değişirler. Her site devletinin ahlak anlayışı farklıdır ve bunların hiçbiri yanlış değildir, çünkü her şeyin ölçüsü insandır. Platon’a göre ise tüm bu erdemlerinin kaynağı idealar âlemidir. Onların görüntüleri, gölgelerin duvara yansıması gibi, reel hayatta farklı farklı olur (Maclyntre, 2001, s. 19-21).

Bugünkü tabirle postmodern olarak nitelenebilecek olan sofistlerle Sokratik felsefenin kavgası öznel ve nesnel aklın kavgası olarak okunabilir. Nesnel aklı savunan düşünürlere göre akıl yalnızca bireyin zihninde değil insanın dışındaki her şeyde, diğer insanlarda, eşyada, tabiatta, var olan bir şeydir. İnsan ve insanın amaçları da dâhil olmak üzere bütün varlığı kapsayan bir sistem vardır. Öznel aklı dışarıda bırakmayan bu görüş bütünlük içinde uyumun sağlanmasıdır (Horkheimer, 2010, s. 56). Öznel akıl görüşüne göre, akıl yalnızca bir amaçla bağlantısı doğrultusunda kabul edilir. Aklın kendisine uygun bir amaç yoktur. Akıl ancak bir amaca ulaşmak için araç konumundadır (Horkheimer, 2010, s.56).

Antik Yunan'dakine benzer bir süreç, bu defa tersinden olmak üzere, aydınlanma sonrası Avrupa'sında yaşandı. Araçsal aklın (reason) tahakkümü Akl’ı (intellect) parçaladığı gibi insan benliğini de parçaladı. Evrensel bir insan doğası düşüncesi yıkılmaya başladı ve her şeye hâkim olan rasyonellik benliklerde boşluklar oluşturdu. Doğayı benliğinden ayıran araçsal akla sahip insan, doğayı egemenliği altına almaya çalıştı. Bu egemenlik başarılı olduğu ölçüde ilerleme ve konfor arttı. Ancak bu durum azgın bir egonun oluşmasını engelleyemedi. Horkheimer, ego'yu sonsuz bir var olma ısrarı olarak tanımlar (Horkheimer, 2010, s. 130) ve “insanın doğayı egemenlik altına almaya çalışmasının tarihi aynı zamanda insanın insanı egemenlik altına almasının tarihidir" der (Horkheimer, 2010, s. 128).

\section{Kamusalın Dönüşümü ve Benlik}

Ferdinand Tönies'in modernleşme paradigmasını açıklamak için ortaya attı̆̆ı cemaat (gemeinschaft) ve cemiyet (gesellschaft) ${ }^{2}$ kavramları benlik inşasının açıklanma-

2 İlgili kavramlar için Ferdinand Tönnies’in “Gemeinschaft ve Gesellschaft” isimli makalesine bakılabilir; bkz. 
sında da önemli rol oynar. Geleneklerin egemen olduğu cemaatte, ilişkiler daha keskin sınırlar içinde ortaya çıkar ve dayanışma daha mekaniktir. Sanayi toplumunun yükselişi ve Horkheimer'ın yukarıda belirttiği araçsal aklın tahakkümüyle eş zamanlı olarak ortaya çıkan cemiyet kavramı ise iş bölümü ve organik ilişkilerin belirleyici olduğu ve duygudan ziyade aklın ön plana geçtiği bir toplumsal ilişkiler ağını işaret eder. Toplumdaki güven ilişkileri de bu bağlamda bir dönüşüme uğrayacaktır. Benlik inşasıyla kişisel güven ilişkilerinin yakından bağlantılı olduğunu vurgulayan Giddens, bu durumu kamusal alan ve mahremiyetin dönüşümü bağlamında açıklar (Giddens, 2010, s. 105-114).

Giddens arkadaşlık kavramı özelinde akrabalık ve diğer yakın ilişki türlerini irdeler. Giddens’a göre fazlasıyla kurumsallaşan kamusal alan özel alanın giderek azalmasına, referans noktalarını yitirmesine ve bunun sonucunda insanın, öznelliğe doğru kaçarak, anlamı iç benliğinde aramasına neden olmuştur. Güçlenen modern kurumlar geniş yaşam alanlarının yerine geçer ve burada daha önce oluşmuş olan anlamı boşaltırlar (Giddens, 2010, s. 106).

Arkadaşlık kavramı da işte bu boşalan anlamlardan biridir. Cemaat toplumunda (gemeinschaft) arkadaşın karşıtı olan "düşman” ve "yabancı” kavramları "meslektaş", "tanıdık”, "tanınmayan biri” gibi formlara dönüşmüştür. Onur bağlılıkla, içtenlik sahicilikle yer değiştirmiştir (Giddens, 2010, s. 109). Böyle bir yapıda soyut sistemler kişisel güvenin yerini alır. Ancak soyut sistemlerin verdiği güven hissi modern öncesi toplumdaki kişisel güvenin sağladığı karşılıklılık ve mahremiyeti sağlayamaz (Giddens, 2010, s. 105). Kişisel güven tarafların üzerinde çalışacakları bir proje halini almıştır ve bireyin benliğini ifşsa etmesine dayanır (Giddens, 2010, s. 111).

Giddens'la paralel olarak Sennett de Kamusal İnsanın Çöküşü’nde kamusal alan ile özel alanın sınırlarının nasıl dengesizleştiğini ve bunun sonucunda bireyin benliğinin nasıl bireyin kaygısı haline geldiğini anlatır. Sanayi kapitalizmi ve sekülerleşmeye bağlı olarak birey, kamusal alanın silindiği bir mahremiyet toplumunda yaşamaktadır. Sanayi kapitalizminin etkisi tüketim üzerinden kamusal alanı dönüştürmeye başlar (Sennett, 2010, s. 45). 1852'de Paris’te açılan Bon Marche mağazası bir şey satın almaksızın mağaza içinde dolaşma imkânı ile düşük ve sabit fiyat garantisi sunar. Müşteriler kendi iradeleriyle seçtiklerine inandıkları kıyafetlere özel anlamlar yükler. Bu durum kamusal göstergelerin ayrıksı özelliğini ortadan kaldırdığı gibi bireyi piyasada pasif bir duruma sürükleyerek tüketici konumuna indirger (Sennett, 2010, s. 190-191). Sekülerleşme ise aşkın bir doğa algısını yıkarak yerine içkin bir algı koyar. Buna göre gerçeklik anlık ve olgusaldır. Artık nesneler ve insanlar ancak bir dizge içinde anlamlı oldukları zaman gerçekliğe kavuşmaz. Ne kadar önemsiz görünürse görünsün her şey kendi başına bir gerçekliktir.

Bu süreçte aile, bireyin benliğini koruma alanlarından biri haline gelir. Kamusal alan ahlaki düşkünlüğün yaşandığı istikrarsız bir konumdayken aile yüksek ahlakın var olduğu ve her türlü kötülükten uzak ideal bir sığınma alanı konumuna getirilir. Kamusal alandan yavaş yavaş evlerin salonlarına çekilen birey, içindeki tanrı bunalımı-

Ahmet Aydoğan (ed.), Şehir ve Cemiyet, İstanbul, İz Yayıncılık, 2000, s. 185-218. 
nı, benliğine özel bir anlam atfederek aşmaya çalışır. Artık karakter irade dışı olarak açığa vurulabilmektedir. Bu sebeple birey kendini savunmalıdır. Bunu da geri çekilerek ve sessiz kalarak yapar. Kamusal alanda yabancilarla konuşmamak bir kural halini almıştır. Bireyin kamusal alanda duygusal olarak yaralanmadan var olabilmesi için sessizliğini koruması gerekir. Kamusal davranış bir gözlem ve pasif katılım durumuna indirgenmiştir.

Modern şehrin kişi dışı ve samimi olmayan kamusal alanı bireyin, kendi benliğine ve deneyimlerine eğilmesine sebep olur. Temelde sanayi kapitalizmi ve sekülerleşmenin meydana getirdiği bu durum narsisizmi ve reddedici cemaat anlayışının yüceltilmesini beraberinde getirir. Modern kamusallıkta yaşayan birey için kişisel yakınlığın manevi açıdan iyi olduğu, bireysel kişiliğin samimi ve yakın ilişkilerle geliştirilebileceği ve bütün kötülüklerin kişi dışılık ve yabancılaşmadan kaynaklandığı düşüncesi geçerlidir. Sennett'e göre modern birey kamusal alanı bir başkasına açılma fırsatı olarak gördükçe toplumsal hayatın rahatsız edici koşullarını değiştirme imkânı yok olmaktadır. Bu da bir taraftan narsisizme sebep olurken bir taraftan da bireyin kendini var etme imkânı olarak gördüğ̈̈ ve ilkel bir düzende işleyen reddedici bir cemaatin (gemeinschaft) ortaya çıkmasına sebep olur.

\section{Postmodern Dönem ve Hakikatin Kaybı}

Featherstone modernizmi, geleneksel karşıtlığ1, ekonominin ve yönetimin rasyonelleşmesi olarak tanımlar (Featherstone, 2005, s. 21-22). Postmodernizm ise geç kapitalizm olarak adlandırılan II. Dünya Savaşı sonrasındaki tüketim toplumunu işaret eder (Jameson 1984'den aktaran Featherstone, 2005, s. 23). Bu dönem tüketim ilişkilerinin farklılaşmasıyla beraber üretim ve çalışma hayatındaki değişimi de beraberinde getirir.

Sennett'in, geç kapitalizmin iş yaşamındaki bireyin kişiliği üzerine etkilerini soruşturduğu Karakter Aşınması isimli kitabında iki farklı kuşağı, baba ve oğlu olan Enrico ve Rico’yu karşılaştırır. Enrico tüm çalışma hayatını tek bir kurumda geçirmiş, uzun dönemli iş arkadaşlıkları olan, oğlunu okutmak gibi kendine ulvi bir gaye edinmiş olan bir iş̧̧idir. Hayatındaki bu istikrar aile ve mahalle hayatı için de geçerlidir. Enrico'nun iş arkadaşlıklarında olduğu gibi komşuluk ilişkilerinde de bir devamlılık söz konusudur. Geç kapitalizmin esnek iş yaşamı içinde çalışan bir mühendis olan Rico ise devamlı iş değiştirmek zorundadır. İş hayatındaki bu kesiklik komşuluk ilişkilerine de yansır. Çünkü işiyle beraber çoğu zaman evini de taşımak, şehir ve muhit değiştirmek durumunda kalır. Böylece hem iş arkadaşlıkları hem de komşuluk ilişkileri uzun süreli değildir. Bu yeni dünyada kimse kimsenin yaşamına başından sonuna kadar şahit olmaz. Hayat fragmanlar halinde yaşanır. Esnek iş hayatı devamlılıkla beraber Enrico'nun bir zamanlar kendini adadığı gibi bir ulvi gayeyi de ortadan kaldırır (Sennett, 2012, s. 13-30). Yeni dönemin hâkim paradigması belirsizlik ve istikrarsızlıkla beraber gelen gelecek perspektifinin çökmesidir. Böyle bir dünyada benlikler bütünlüklerini yitirirler ve parçalanmış benlikler ortaya çıkar.

Meselenin bir boyutu iş ve aile hayatının parçalanmasıyken diğer bir boyutu çağdaş bireyin "boş zamanını" dolduran tüketim ve onun ideolojiye dönüşmüş hali olan 
tüketim ideolojisi (consumerism) dir. Frankfurt Okulu temsilcilerinin ortaya att1ğ1 bir kavram olan kültür endüstrisi 1929 dünya ekonomik buhranının bir sonucu olarak literatüre girer. Erken kapitalizm olarak adlandırdığımız 19. yüzyıl ekonomik dünyasında üretim odaklı bir ekonomi anlayışı vardır. Bu anlayışa göre daha fazla kazanmanın tek yolu daha fazla üretim yapmaktır. Birim zamana düşen üretimi artırmak adına yapılan verimlilik ve motivasyon gibi ampirik ve teorik çalışmalar genellikle bu ekonomik bakış açısının ürünü olmuştur. Dolayısıyla bu dönemde işçi ücreti bir maliyet unsuru olarak kabul edilir. Bir ürünün maddi değerinin içinde belli miktarda işçi ücreti vardır. Bu ücret düşürüldükçe kârlılık artarken ücret artırıldıkça kâr marjı düşecektir.

1929 krizinin ardında yatan temel etken arz fazlalığ fakat talep yokluğudur. Piyasaya sürülmeye hazır ihtiyaçtan fazla ticaret eşyası depolarda beklerken piyasada bu ürünleri satın almaya yetecek alım gücü kalmamıştır. Bu da işçi ücretlerinin yalnızca bir maliyet unsuru değil aynı zamanda bir alım gücü olduğu gerçeğini de ortaya koymuştur. II. Dünya Savaşı sonrasında ekonomi anlayışı üretim odaklı olmaktan tüketim odaklı olmaya doğru bir seyir takip eder. Yeni kapitalizm olarak adlandırd1ğımız bu dönemde üretimde farklılaşmanın yanı sıra farklı tüketim alanları da oluşturulmaya başlanır. Ancak kapitalist üretimi gerçekleştiren çalışanların sistemi döndürebilmeleri için kazandıkları parayı yeniden dönüşüme sokmaları gerekir. Bu da çalışmaktan arta kalan zamanda bir "boş zaman” kavramının inşa edilmesi demektir.

Boş zaman yeni kapitalizmin ayakta durmasını sağlayan bir araçtır. Fakat bunun için insanlar boş zamanlarında kişisel ve özgür tercihler yapmak yerine yine kapitalizmin belirlediği kontrollü bir alanda faaliyet göstermelidirler. Sınırları belirlenen ve kontrol altında tutulan boş zaman faaliyetlerinde insanlar daima belirlenmiş kalıplar içinde kalmalı fakat özgür seçimler yaptıklarını zannetmelidirler.

Adorno ve Horkheimer’n kullandığı kültür endüstrisi kavramı popüler kültür ve kitle kültürü kavramlarından sonra kullanılır. Çünkü bu son ikisinde halk kültürünü anımsatan ve bireyi özne durumuna koyan bir eğilim söz konusudur. Kültür endüstrisi kavramı ise insanın tamamen nesne durumuna düştüğü bir alanı işaret eder. Yeni kapitalizm ile ortaya çıkan boş zaman işte bu kültür endüstrisinin ürünleriyle doldurulur, daha doğrusu yönlendirilir. Bu yeni modern/postmodern insan tüm mesaisini kapitalizmin üretim faaliyetleri için harcayarak bunalırken kendine ayırdığını zannettiği boş zamanda kültür endüstrisinin ürünlerini tüketerek sistemin varlığını sürdürmesini sağlar (Adorno ve Horkheimer, 2010, s. 162-171).

Bütün bu kavramlar çerçevesinde düşünüldüğünde 20. yüzyılın ortalarından itibaren yeni bir benlik tanımı ortaya çıkar. II. Dünya Savaşı sonrası Amerika Birleşik Devletlerinde yükselen refah toplumu (welfare) ilerlemeci modern bir toplum oluşturmasına rağmen tatminden uzak ve patolojik bir benlik geliştirmeye başladı. Geleneğin ve paylaşılan anlamın yokluğunun sebep olduğu bu benlik türüne Amerikalı psikolog Philip Cushman "boş benlik" adını verdi. İleri kapitalist toplumların atomize olmuş bireyi aile, toplum, gelenek gibi değer yüklü irtibatları kaybettiği için bir duygusal açlık içerisine düştü. Bu tür bağlardan azade olmuş, başka bir ifadeyle boşalmış olan 
benlik, bu boşluğa ve parçalanmışlığa karşı koyabilmek için bazı savunma mekanizmaları geliştirdi (Sayar, 2008). Tüketim odaklı olan ve tüketimin farklı türleri olarak ortaya çıkan bu savunma mekanizmaları beden estetiğinden satın alınan veya sahip olunan metaların yüceltilmesine kadar çok geniş bir yelpazede ortaya çıktı.

\section{Narsisist Benliğin Ortaya Çıkışı}

Narsisizm ilk bakışta "kendililik sevgisi" olarak tanımlanırken bu durum esasında bir paradoksun ürünüdür. Lash, Sennet' in Kamusal İnsanın Çöküşü̈nde dikkat çektiği, narsisizmin kendini sevmekten ziyade kendini sevmemekten kaynaklandığı tezini destekler. Bu noktada Fromm’u eleştirir ve onun kendini sevmek üzerine verdiği vaazlarla, bu patolojinin esasında kendini sevmemekten kaynaklandığı gerçeğini kaçırdığını söyler (2006, s. 66). Cushman'la benzer şekilde Lash, narsisizmin temelde kendilik sevgisinden çok saldırgan dürtülere karşı bir savunma olduğunu (s. 67) ve reddedilen sevginin kendiliğe nefret olarak geri döndüğünü (s. 71) savunur. Narsisizm üst ben ile id'in savaşı şeklinde ortaya çıkar. İd'in arzuları ile üst ben (süper ego) çatıştıkça zaten boşlukta konumlanmış olan benlik kendini aciz ve sevgiden mahrum bırakılmış hisseder. Bunun bir sonucu olarak benlik kendini yüceltir ve dünyanın merkezinde konumlandırır.

Bu kendine odaklanmış birey tasavvuru atomize olmuş birey figürüyle ilişkilendirilebileceği gibi tarihin sonu düşüncesiyle de yakından ilgili görünmektedir. İlerlemeci tarih algısında var olan tarihin sonu tezleri 20. yüzyılda, bu defa kapitalist bir bakışla yeniden gündeme gelir. Liberalizmin alternatifsizliğini vurgulayan Fukuyama’nın "Tarihin Sonu" ve Bell'in "İdeolojinin Sonu" benzeri tezlerle toplumların bir geleceği olduğu fikri zihinlerde sorunlu hale gelir. Dolayssıyla artık geleceği olmayan bir toplum anlık yaşamaya ve birey de aşkın bir biçimde kendine odaklanmaya başlar (s. 25). Modern öncesi toplumlarda insanlar benlik üzerine yoğunlaşmak yerine biz bilinci üzerine yoğunlaşan ve "yalnızca tek bir yaşamım var" düşüncesi yerine atalarının ve çocuklarının hayatlarını da yaşayan insanlardı (s. 27). Oysa refah toplumunun insanı parçalanan bu tarihselliğin içinde boşalan benliklerini kendini yücelterek doldurmaya çalışır.

Twenge ve Campbell Narsisizm İlleti isimli kitaplarında narsisist nesli ben nesli olarak tanımlarlar. Ben nesli fedakârlık, sadakat, vefa gibi değerleri yok sayan ve bunun yerine "kendin ol" düsturunu yerleştiren bir hayat felsefesine sahiptir. Her alanıyla yaşamın kendisi bir kişisel ifade biçimini alır. Farklı olmak, kendini ifade etmek, duygulara aşırı önem vermek yaşamanın tek amacı haline gelir (Twenge ve Campbell, 2010). Rousseau'nun duyguya yaptığı atıfla ortaya çıkmaya başlayan modern birey duygu ve hissetme üzerine bina ettiği benlik kurgusuyla patolojik bir hal alır. Descartes'in bilen benlikle bilinen benliği ayırdığı özdeyişi "cogito ergo sum", narsist bireyde "sentio ergo sum" (hissediyorum o halde varım) şekline dönüşür. 1940'lı yıllarda doğanların temel değerleri çalışkanlık, dürüstlük, başkalarına saygılı davranmak şeklinde ortaya çıkarken ben neslinin temel değerleri mutlu olmak ve hislerimize önem vermek biçiminde değişir. Duygulara yapılan bu vurgulara rağmen ben nesli depresyonun, anksiyetenin ve çeşitli psikolojik hastalıkların pençesindedir. 
William James ağrıya ve acıya katlanmayı ve sabrı benliğin gelişimi açısından tavsiye ederken bu yeni ben nesliyle beraber acılar katlanılması gereken değil ilaçla tedavi edilmesi gereken sorunlar olmuştur (Sayar, 2008).

Lash, postmodern toplumda göz ardı edilemez şekilde ortaya çıkmış olan narsisizmin derin bir soruşturmasını yaptığı Narsisizm Kültürü isimli kitabında, bu patalojinin kaynakları olarak ailelerin kültür aktarımı rolünün sekteye uğramasını, geçmişle bağ kurma duygusunun çökmesini, geleceğe dair perspektifin kalmamasını, büyük bürokratik örgütlenmelerin egemenliğini ve kitle iletişim araçlarının yoğun etkisini gösterir.

Tüketim toplumunun doyumsuz, kaygılı ve huzursuz bireyi reklamların tüketim propagandası altında yeniden üretilen bir metaya dönüşmüştür. Bu tüketim evreninde mesajın doğruluğu veya yanlışlığı değil inanılırlığı ön plana çıkar. Eğer bir mesaj inandırıcıysa yanlış olması önemli değildir. Hakikat inanılır görünmüyorsa onu örtbas etmek gerekir. Bu görünenin kutsandı̆̆ı bir evrendir (s. 130). Tüketim toplumunda seri üretim mallarının birer yanılsama olarak fazlaca gösterilir kılınması bunların temsil güçlerini zayıflatır ve gerçekliği tepe taklak eder. Gerçeklik yanılsaması, gerçeğin yerine geçen güçlü bir gerçeklikte değil, gerçekliğe karşı duyulan güçlü bir umursamazlıkta ortaya çıkar.

Birey her türlü sosyal ortamda birilerinin bakışları altında devamlı rol yapar. Gerçekte farklı ruh hallerinden, iniş ve çıkışlardan oluşan insan bu sürekli bakışlar altında kesintisiz bir rol sahnelemelidir. Bu da "ruhun bürokratikleşmesi" ve yüksek bir benlik bilincinin oluşmasına sebep olur (s. 151). Nüfuz edilemez ilişkiler ağı içindeki birey bir gösteri objesidir. Farklılıklarını vurgulayarak ve sürekli çekici görünerek kendini var kılmaya çalışır. Sahici duygu ve düşünceleri yerine toplumun beğenisini celbeden şeyleri hissetmeli ve düşünmelidir (s. 155). Eskinin alın yazısını kötüleyen insanı, artık kendilik bilincinin mahpusluğunda alın yazısını özler duruma gelir (s. 162-163).

Modern okul sadece eğitimin değil sosyalleşmenin de bir aracı haline geldiği için ailenin ve kilisenin görevlerini de üstlenir (s. 217). Devlet ve bürokrasi ailenin yerine geçer. Karmaşık bir bürokrasiyi beraberinde getiren sosyal hizmet kurumları, tıp ve psikiyatri, reklamlar ve pazarlama endüstrisi çocuğun yetişmesinde ebeveynlerden daha çok söz sahibi olmaya başlar. Doğum uzmanları, çocuk hekimleri, öğretmenler, gıda endüstrisi ve televizyon çocuk gelişimindeki sorumluluğun çoğunluğunu üstlenir. Ailenin çocuğa verecek sevgiden başka pek bir şeyi kalmamıştır fakat bu disiplin içermeyen sevgi kuşak sürekliliğini sağlamak için yeterli değildir. Ebeveyn çocuğa yol göstermek yerine ona yetişmeye çalışır hale gelir ve kendiliğinden ortaya konan duygular yerine çeşitli çocuk yetiştirme yöntemlerini takip etmek zorunda kalır (s. 251-259).

Baba otoritesinin ortadan kalkması da yeni bir patolojiye sebep olur. Endüstriyel üretimle beraber babanın evde daha az bulunması çocuğun bilincindeki otoritenin azalmasına sebep olur. Baba otoritesinin çöküşü süper ego değerlerinin egemen olduğu bir toplumdan id değerlerinin egemen olduğu bir topluma geçilmesine neden 
olur. Ortadan kalan baba otoritesinin yerine büyüklenmeci kendilik imgeleriyle kaynaşmış arkaik ebeveyn imgelerine dayanan sert ve cezalandırıcı bir üstben ortaya çıkar. İşte narsisizmin ortaya çıkışı böyle "hoşgörülü" bir ortamda oluşur (s. 276-282).

Ebeveyn çocuk ilişkisinde geçerli olan zayıflayan bağlar teorisi kadın erkek ilişkileri için de geçerlidir (s. 295). Çocukla sonuçlanmayan cinsel birliktelik, kadının özgürleşmesi ve anlık yaşam gibi sebeplerden dolayı kadın erkek ilişkileri geçicilik üzerine kurulmaya başlar. Duygusal bağlardan uzak durmaya çalışan ve sürekli ilişki için söz veremeyen çiftler kimseden de böyle bir söz talep edemezler. Bu durum kıskançlğ̆ın bir tür suç olarak algılanmasına sebep olur (Lash, 2006, s. 300). Birliktelik duygusal karmaşaya sebep olurken bundan kaçmanın yolu rastgele cinsel ilişkidir. Duygusal karmaşadan kaçış özgürleşmeyi getirirken bağlayıcı olmayan soğukkanlı seks "ilerici bir ideolojidir". Bu ideoloji duygusal bağlardan uzak durmayı bir erdem gibi gösterir (s. 311-312).

Modern toplumda yaşlılık da bir problem olarak görülür. Çalışma hayatının yeniden örgütlenmesi yaşlıları hayatın dışına atarken onlardan birer deneyim bilgesi olarak yararlanmayı da reddeder. Toplumun bu dışlaması insanları daha orta yaşlara geldiklerinde korkutmaya, akıldışı bir paniğe sürükler (s. 326-327). Bu sebeple yaşlanma istenmeyen bir şeydir. Dolayısıyla insanlar yaşlanmamak için daha doğrusu yaşlı görünmemek için bir illüzyona başvururlar. Bu illüzyon görmenin kutsandığı modern dünyada yaşam tarzlarını değiştirmek, örneğin genç gibi giyinmek, fit olmaya çalışmak, gençlerin yaptı̆̆ " "çılgınlıkları" yapmak şeklinde ortaya çıkar. Dünyayı bir oyun sahnesi olarak gören birey kendinden sonra sahneye çıkacak olan çocuklarına bu sahneyi kolaylıkla terk etmeye gönüllü değildir. Tarihsel zaman duygusunda ortaya çıkan bu köklü değişiklik daha önce de belirtildiği gibi bir gelecek perspektifi sunmamaktadır. Bu yüzden narsisist özellikler gösteren böyle bir toplumda insanlar ölümü ve yaşlanmayı kabullenmek istemezler (s. 332-337).

\section{Sonuç}

Premodern dönemde kontrol altında tutulması hatta tahkir edilmesi gereken bir şey olan benlik tanrıya ulaşmanın da bir aracı konumundaydı. Ayrıca "kendini bilen Rabbini bilir" düşüncesinden hareketle aşkın bir kendini bilmenin, benlik üzerine tefekkür etmenin ontolojik bilginin en temel gerekliliği kabul ediliyordu. Bu sebeple benlik tasavvufun, daha geniş bir ifadeyle metafiziğin bir konusu hükmündeydi.

Rasyonel ve ölçülebilir olma derdini her şeyin merkezine koyan modern bilim tüm metafizik ilimleri rasyonel olmadığı gerekçesiyle meşru alanın dışına itince benlik gibi gerçekte metafiziğin alanına giren konular rasyonel bir indirgemeciliğe tabi tutuldu. Meselelerin ölçülebilir tarafları önemsenirken ölçülebilmesi mümkün olmayan tarafları ilgi alanı dışına atıldı.

Antik Yunan'dan aydınlanmaya, sanayi devrimine ve kapitalizme, kültür endüstrisine ve boş zamanın icadıyla ortaya çıan tüketim toplumuna doğru bir benlik okuması gerçekleştirmeye çalıştık. Modernizmin ve özellikle postmodernizmin meydana getirdiği bürokratik kurumların otoriteyi soyut hale getirmesi, mahremiyetin ve 
kamusalın çöküşü bunun sonunda da narsisist bireyin ortaya çıkışını gördük. Bütün bu süreçler aynı zamanda kutsalın merkezi konumunu yitirişi ile derinden ilişkilidir. Benliği parçalamayan, varlığı bütünlüklü algılayan premodern insanın tasavvurunda bilgi, ancak kutsalın bilgisiydi. Tek ve değişmez hakikat telakkisi, bir güneş ışınının prizmadan geçmesiyle farklı renklerdeki ışınların ortaya çıkması gibi, reel dünyada farklı görünümlere sahip olabilirdi. Fakat nihai olarak hakikati yanılsamadan, doğruyu yanlıştan, Hakkı batıldan ayıran bir ölçünün varlığı tartışmasızdı. Söz konusu süreçler sonunda gelinen nokta ise değişmez bir hakikatin inkârı, izafiliği ve bilinemezliğidir. Tanrı tasavvurunu yok sayan modernizmden sonra, şimdi de postmodernizm her türlü hakikat telakkisini bilinemezciliğe mahkûm etmektedir. Tanrı ve hakikat tasavvurları bu izafiliğe tutsak edildiğinde ortaya çıkan şey, insanın kendi benliğini tanrılaştırması olmuştur.

\section{Kaynakça}

Adorno, T., Horkheimer, M. 2010. Aydınlanmanın Diyalektiği. Çev., Elif Öztarhan. İstanbul: Kabalcı Yayınları.

Akarsu, B. 1998. Felsefe Terimleri Sözlüğü. İstanbul: İnkılap Yayınları.

Aydoğan, A, ed. 2000. Şehir ve Cemiyet. İstanbul: İz Yayıncılık.

Bolat, A. 2003. Melametilik / Bir Tasavvuf Okulu Olarak. İstanbul: İnsan Yayınları.

Camus, A. 2002. Sisifos Söyleni. Çev.,Tahsin Yücel. İstanbul: Can Yayınları.

Cevizci, A. 2012. Felsefeye Giriş. İstanbul: Say Yayınları.

Drever, J. 1952. A Dictionary of Psychology. Baltimore: Penguin Books.

Ekşi, F. 2012. Kişisel gelişim Kitapları. İstanbul: Kaknüs Yayınları.

Featherstone, M. 2005. Postmodernizm ve Tüketim Kültürü. Çev., Mehmet Küçük. İstanbul: Ayrintı Yayınları.

Foucault, M., Gutman, H., Hutton, P. 2001. Kendini Bilmek. Çev., Gül Çağalı Güven. İstanbul: Om Yayınevi.

Giddens, A. 2010. Modernliğin Sonuçları. Çev., Ersin Kuşdil. İstanbul: Ayrıntı Yayınları.

Gündoğan, A. O. 1995. Albert Camus ve Başkaldırma Felsefesi. Erzurum: Birey Yayıncilik.

Horkheimer, M. 2010. Akıl Tutulması. Çev., Orhan Koçak. İstanbul: Metis Yayınları. Hume, D. 1978. A Treatise of Human Nature. New York: Oxford University Press.

Kant, I. 2001. Pratik Usun Eleştirisi. Çev., İsmet Zeki Eyuboğlu. İstanbul, Say Yayınları.

Lasch, C. 2006. Narsisizm Kültürü. Çev., Suzan Öztürk, Ümit Hüsrev Yolsal. Ankara: Bilim ve Sanat Yayınları.

Maclntyre, A. 2001. Etik'in Kısa Tarihi. Çev., Zelyut Hünler. İstanbul: Paradigma Yayınlar1.

McLuhan, M. 2011. Gutenberg Galaksisi. Çev., Gül Çağalı Güven. İstanbul: Yapı Kredi Yayınları.

Nasr, S. H. 2012. Bilgi ve Kutsal. Çev., Yusuf Yazar. İstanbul: İz Yayınları. 
Nurbahş, C. 2009. Sufi Öğretisinde İnsan ve İnsan Psikolojisi. İstanbul: Kurtuba Yayınları.

Ong, W. 2013. Sözlü ve Yazılı Kültür. Çev., Sema Postacıŏlu Banon. İstanbul: Metis Yayınlar1.

Rousseau, J. J. 1991. İtiraflar II. Çev., Arif Obay. İstanbul: MEB Yayınları.

Sartre, J. P. 2002. Varoluşçuluk. Çev., Asım Bezirci. İstanbul: Say Yayınları.

Sayar, K. 2008. “Benlik: O Yakın Soru, O Uzak Ülke”, Erişim: 8 Kasım, 2013, http://www.kemalsayar.com/sayfalar.asp? $s=36$.

Sears, D. O., Taylor, S. E., ve Peplau, L.A. 2010. Sosyal Psikoloji. Çev., Ali Dönmez. İstanbul: İmge Kitabevi.

Sennett, R. 2010. Kamusal İnsanın Çöküşü. Çev., Serpil Durak, Abdullah Yılmaz. İstanbul: Ayrıntı Yayınları.

Sennett, R. 2011. Otorite. Çev., Kamil Durand. İstanbul: Ayrıntı Yayınları.

Sennett, R. 2012. Karakter Aşınması. Çev., Barış Yıldırım. İstanbul: Ayrıntı Yayınları.

Twenge, J. M., Campbell, W. K. 2010. Asrın Vebası: Narsisizm İlleti. Çev.,Özlem Yüksel. İstanbul: Kaknüs Yayınları.

Yalçın, Ş. 2008. "Kant ve Benlik.” Kaygı, 11, s. 91-101.

Yanbastı, G. 1996. Kişilik Kuramları. İzmir: Ege Üniversitesi Edebiyat Fakültesi Yayınlar1.

Yıldız, M. 2006. “Benlik-Kavramı ve Benliğin Gelişiminde Dinin Rolü”. Dokuz Eylül Üniversitesi İlahiyat Fakültesi Dergisi, 23, s. 87-127. 
Transformation of Knowledge and Sacred from Premodern to Postmodern: The Sacred Perception of Narcissist Self

\section{AHMET GÜVEN}

Abstract: To clarify the concept of the self, it is necessary to consider the term in two periods as premodern and postmodern. The transformation realized in the essence of the "information" by modern thought, changed initially the perception of the self and then inevitably the perception of sacred. The sacred knowledge (scentia sacra) which had a central place in traditional thought entitled self to exist only in divine intelligence (intellect) and the tradition regarded the self as the personality which must be disciplined. However, modern thought made a separation between the self that knows and the self that is known, and desacralized the information by shifting the center of the information from divine to the human one. The thought about the relativity of the truth which based on idea of the inaccessibility of the truth was born in postmodern times as a reaction to the perception of the one dimensional and imposing truth of modernism, which once replaced the traditional conception of multi layered truth. That postmodern thought is the most important factor in the emergence of the narcissist self.

Keywords: Knowledge, Self, Narcissist Self, Sacred, Scentia Sacra. 